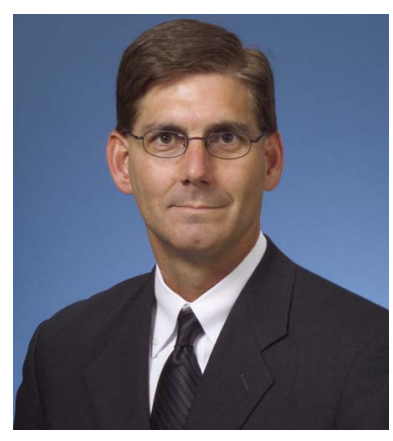

\title{
Change in 2010
}

Things change. I think this might have been Newton's fourth law of motion. Then again, it is probably covered by Newton's first three laws. This month marks a change in the editorship of $O p$ tical Engineering. There are two topics that I would like to cover associated with this change.

First, I would like to introduce myself. Professionally, I am the superintendent of the Optical Sciences Division at the Naval Research Laboratory in Washington, DC. I work with a brilliant group of scientists and engineers who research and develop everything from quantum dots to airborne sensors for missile countermeasures. I've been in this job for two years. For the previous 12 years, I worked for the Army Night Vision Laboratory where I headed a division responsible for modeling the performance of military imagers (target acquisition and surveillance). Personally, I am the father of a 25 -year-old son and 11year-old triplets (two daughters and a son). Their latest hobby is Facebook. I love to watch college basketball with some of my close friends. I feel very fortunate to have chosen optical engineering as my career field and I am thankful (and honored) for the opportunity to be the editor of Optical Engineering.

Second, I want to say a few words about Don O'Shea and acknowledge all that he has accomplished as the editor of Optical Engineering. Don served as editor from 1998 through 2009 (with one year off as SPIE president in 2000). During this time, Optical Engineering received over 9,300 submissions and published over 5,100 papers and over 36,000 pages. Don established the editorial board in 1998 and created the Optical Engineering Letters section of the journal in 2001 (in which 310 letters have been published out of 890 submissions). He was also part of the transition to digital publishing. Full-text HTML and reference linking were added to the journal in 2001 and free online color was introduced in 2003. Optical Engineering became part of the SPIE Digital Library in 2003. Don also helped the journal transition to an online peer review process in 2004. The journal began to accept multimedia in 2007. Finally, the time from acceptance to publication was reduced by nearly $50 \%$ in 2008.

Don came to Optical Engineering as a professor at Georgia Tech and his commitment to serving the optical engineering community included a number of roles besides editor. A few of the more important roles were as the creator of the OSA Optics Discovery Kit, as an author of undergraduate and graduate text- books on lasers and optical design, as an active member of SPIE and OSA leadership, and as an educator (he was awarded the Esther Hoffman Beller Award for excellence in the field of optics education).

Don is one of a handful of people that I have used as a mentor over the years, where I didn't hesitate to pick up the phone and ask him what he thought. I didn't have to worry about him sugarcoating his point of view. This was this and that was that. I valued his input more than he ever knew and, more recently, I have really enjoyed his friendship. I hired his son as an Army scientist some six or seven years ago and it was great to find out that brilliance ran in the family gene pool. His son moved to Huntsville, Alabama, and now works in a group that I used to work with in the area of imaging system testing. I now keep tabs on both Don and his son through mutual friends in the small community of optical engineers.

In August, Don and I went to a Padres baseball game in San

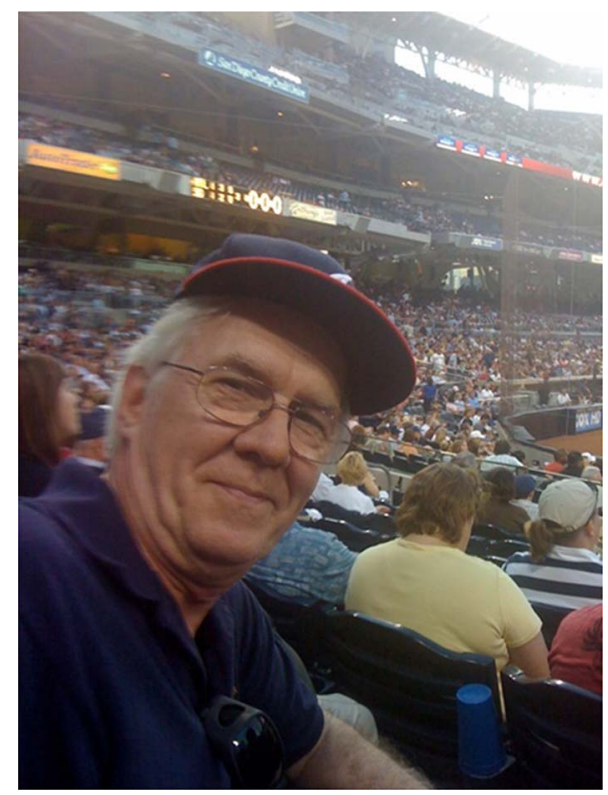

Fig. 1 Don O'Shea at San Diego's PETCO Park. 
Diego during the SPIE Optics and Photonics Meeting. Since the Braves were playing, Don was pulling for the visitors and, like a good friend, I pulled for them too. It was a great evening with a chance to spend time with my friend and mentor while watching the Braves win.

Things change. I will miss Don as editor, but he will continue to be a valued mentor. Needless to say, I have some pretty big shoes to fill. However, if he doesn't make it to next year's game, I may pull for the Padres.
Ronald G. Driggers

Editor 